\title{
DEALING WITH STUDENTS' RETICENCE IN SPEAKING ACTIVITY IN EFL CLASSROOM
}

\author{
Jenal Aripin ${ }^{1}$ and Amalul Umam ${ }^{2}$ \\ Islamic Junior High School Al Bina \\ zainalxzainal@gmail.com ${ }^{1}$; amalul.umam@uika-bogor.ac.id ${ }^{2}$
}

\begin{abstract}
Speaking is an activity in an English classroom in which students must integrate not only higher order thinking skills but also confidence. As a result, it can be problematic for students because they feel shy or reticent. This study aimed at finding out the cause of students' reluctance in speaking activities. The study was framed by using classroom action research in which 2 cycles were employed. Each cycle consisted of four stages: planning, action, evaluation, and reflection. There were 40 students in the 7 th grade of junior high school in Bogor as the participants of the study. The data was collected through documentation, observation, and semi-structured interviews. The results showed that the causes of students' reluctance in speaking class were shy, lazy, afraid and ignorance. Giving more students' talk time as a teaching strategy in English speaking activity can be done to reduce students' reticence.
\end{abstract}

Keywords: Speaking, students' talk time, students' reticence

\section{INTRODUCTION}

Speaking is an important skill in an EFL setting (Van den Branden, Bygate, and Norris, 2009) because being able to speak in the classroom activities and to express ideas to strangers in their language which both speakers can understand is the goal of many learners or students (Luoma, 2004). In addition, the connection between students' classroom speaking participation (students-centred) and their academic achievement is undeniable. In addition, Turner (2010) said that the importance of perception of the ability to speak should not be underestimated by either teachers or students.

According to the mandate of Article 31 of the 1945 Constitution of the Unitary Republic of Indonesia concerning Education and Culture, and the realization of the Law of the Republic of Indonesia Number 20 of 2003 concerning the National Education System and Government Regulation Number 19/2005 article 19 paragraph (1) concerning Process standards, learning process in the education unit must be organized in an interactive, inspirational, fun, challenging, and motivating. Students must be given time to actively participate, and be given sufficient space for initiatives, creativity, and independence in accordance with the talents, interests and physical and psychological development of students (BSNP, 2006).

In reality, some teachers admitted that some of their students chose to keep silent in the class than speaking English, even when they know the answer to the teachers' questions. This happened because they felt hesitate to open their mouths, although they knew that they had to speak English in the classroom activities. This situation should have solutions in which teachers must help reticent students to improve their skill and confidence needed to take an active role in oral classroom lessons for the students (Liu \& Jackson, 2009). Moreover, students should be assisted by teachers to work together in the classroom, so they can have the 
opportunity in achieving their academic goals.

This paper aims to find out the reasons behind students' reticence and to increase their motivation and overcome reticence by determining more activities in speaking activities. It is expected to develop students' confidence and ability to speak English in the learning-teaching process in the classroom. Teachers can give more students talk time in the classroom about the lesson that will be discussed to help them largely to speak and develop their ability in speaking English classrooms.

\section{LITERATURE REVIEW}

\section{Speaking in the Curriculum 2013}

Novitasari (2016) says that "speaking is a challenging task for students in language learners because this activity requires the integration of many factors combined". Speaking as an interaction is perhaps the most difficult skill to teach students because interactional speech that occurs in class is a very complex and subtle phenomenon that occurs under the control of unspoken rules (Richards, 2008).

The issue of speaking in teaching English becomes a widespread problem that must be discovered by many researchers. As said by Van den Branden, Bygate, and Norris (2009), the important part of skills in the curriculum language teaching and the ability in a foreign language is speaking skills. In addition, speaking skill is one of the ways used by people in communication to get information, and it's a major function in communicating with others to convey messages to be conveyed properly with written, spoken and written language. The ability to speak is a production capability that produces systematic verbal speech to convey meaning. Thus, learning to speak English is one of the most important things for students, with the current era of globalization where students are required to communicate with other people out there.

According to Regulation number 103 year 2014, there are main competence (KI) and basic competence (KD). Main competence $(\mathrm{KI})$ is descriptions of students' primary competences that includes knowledge, attitude, and skills to be achieved every class or semester in a certain subject which have to be posed by the students. Meanwhile, Basic competence (KD) is several competencies which have to be mastered by the students for a certain subject as a basis for establishing indicator of competence (The minister of Nasional Education 2013). Referring to the Minister of Education and Culture 37 of 2018 about KI and KD for $7^{\text {th }}$ grader, the focus of KD 4 is arranging very short and simple oral communications and written text interactions that involve greetings and saying goodbye.

There are some strategies that teachers must have in implementing the 2013 curriculum. Teachers must act as a learning designer, learning motivator, learning mediator, and learning inspiration (Wachidah, 2013). It means that teachers must be able to stimulate and motivate their students from which the students will feel motivated in their learning processes.

Hatch and Jack C. Richards (2008) emphasize that second language learners need a variety of topics available to manage speech as interaction. Initially, students may depend on topics that are familiar to them. However, they also need to practice in introducing new topics into the conversation to move beyond this stage. According to Brown (2000), teachers' strategy in teaching is a special method for approaching a problem encountered in the classroom. 


\section{Students' Talk Time}

In the 21st century, the development of teaching and learning processes has changed by the times. The traditional practice of teaching teachers with old concepts is outdated and ineffective (Wilhelm, 2014, Danelle, 2017). Giving more student talk time is one of the methods to enable students to lead classroom speaking and conversations to improve their academic and social performance in the class. In modern and diverse classrooms, it is not enough for students to become passive participants; their learning depends on their active involvement in the classroom (Danelle, 2017).

The interaction is very important for students speaking achievement (Gillies, 2014; Danelle, 2017). Increasing students speaking and conversation is a process of increasing social learning in English for all students and give more time in students' verbal discussion with the teachers show students that teachers collaborate in their education (McElhone, 2013; Danelle, 2017). One of the rules for making small talk is to give students more time to start the interaction with comments about something around or that both participants know. Then, students can be given materials about class lessons where they will have small talk or discuss about the materials (Richards, 2008).

Students talk time gives benefits for the students to be active in the English class (McElhone 2013). Furthermore, giving more students' talk time in discussion also makes it easier for students to transfer materials and become meaning-makers (Wilhelm, 2014; Gillies 2014; Danelle, 2017).

Discussion is an effective strategy to be used in speaking activities in large classrooms. This increases the sheer number of learners talk going on in a limited period and also lowers the inhibition of learners who are unwilling to speak in front of the classroom. Discussion is a useful way of assessing the knowledge, skills, and attitudes of students before finalizing instructional objectives that involve the exchange of ideas and opinions among students or students and teacher. Smaldino, Lowther, \& Russell (2005) say that there are some advantages of using the discussion method:

Interesting. Discussions are often more interesting for students than sitting and listening to someone tell them facts.

Challenging. Students can be challenged to think about the topic and apply what they already know.

Inclusive. Discussion provides an opportunity for all students to speak, rather than only a few answering teacher questions.

Opportunity for new ideas. Students may bring new ideas to the information presented. Discussion can be led by the teacher by asking some questions to get students' responses to the lesson in the classroom activity.

\section{Reticence}

The most fundamental factor in the problem of reticence is the students' selfviews in learning the second language. What exactly is meant by students in terms of improving second language skills is not so important as what they think about the second language. So, students see themselves and ultimately determine who they are. (Steven \& Lynn , 2015). Asian learners are often considered to be more reticent than their western counterparts (Tsui 1996) cited in Zhang \& Head (2010). Students' reticence is a major problem for the teachers in their classrooms, and students' comments express frustration at the behaviour of their students who are unable to bring themselves to participate actively in class (Zhang \& Head 2010).

Tsui (1996) believes that students are generally shy and unwilling to speak in 
English and choose to be passive. Most of them simply doing nothing but listening or sometimes daydreaming (cited in Zhang \& Head, 2010). This claim was confirmed in a study that investigated students' reticent beliefs about reticence, where the majority of reticent individuals agreed to the statement, "It is better to remain silent than to risk appearing foolish" (Keaten, 2000). In addition, reticent student is someone who does not anticipate success in communicative transactions involving speech. He explains that reticent individuals are "quite aware" of their incapability, but seek to avoid interactions. Mastering the speaking skill as an interaction is difficult and may not be a priority for all students. They find it difficult to display their good and active self-image in the class by choosing to be quiet and sometimes avoid situations that require this kind of conversation. This can be a disadvantage for students where the ability to speak to participate in classroom activities can be important (Richards, 2008).

Richards (2008) proposes that students must speak out practicing the topic being studied in class so that they are ready to contribute and make the class active. That is, they have to practice saying "yes," "I'm sorry," "sorry, I don't understand," etc., and asking for parts of sentences or materials they do not understand to be explained again by the teacher. Then, there is no stopping, and underestimating the opportunity for students to have a conversation that will cause reticence or the use of "yes" and better silence when students do not understand the materials in English classroom activities. In addition, the lack of opportunities for practice is identified as an important contributing factor for speaking. The effect of this deficiency is the lack of self-confidence of students and often chooses acute silent actions when speaking.

\section{METHOD}

This study was conducted by using a classroom action research in which the researchers used documentation, semistructured interview, and observation as the ways of collecting the data (Creswell, 2012).

The researcher used two cycles in conducting the research. The cycle has the following steps; planning, action, evaluation, and reflection.

Planning is defined as the process of making a plan that develops a program of action that makes sense and is realistic. The plan provides detailed answers to all patent questions involved in carrying out the project. The planning that researchers prepared in this action is collecting the required documents. Documents for the research used here were the curriculum, namely the Curriculum 2013, the syllabus, lesson plan, some tests or worksheets, and the scoring sheets. The researchers designed the lesson plan and used giving more students' talk time in the form of discussion as a teaching strategy to reduce the students' reticence. The types of materials presented in this study are expressions of greeting and leave-taking, expressions of thanking and apologizing. Learning materials used in each meeting were adapted from textbooks

The worksheet was used to see the students' speaking during and after taught by using give more students' talk time as the strategy of teacher in speaking class. It showed whether there will be improvement of students' speaking ability or not by the implementation of actions.

The action of this research was conducted in the teaching and learning process. In the process, students were given more time to talk with their peers, from which they were expected to express more of their ideas in the form of speaking. During the action, observation 
was done to collect some information regarding the application of giving more students' talk time.

\section{Evaluation is a systematic} conclusion that is empirical and methodical by providing credible information that must be reliable, and useful for gathering evidence in social research methods and not as impartial as possible. This was aimed to highlight what are the most discussed topics in the current literature in order to have a clearer picture of the actual state of the debate. In this study, the evaluation was done after each action was completed by checking the notes during observation and the lesson plan applied. To support this data, semi-structured interview was conducted, to validate the missing information from observation and documentation.

Reflection can lead to an analysis of actions in such a way that it can be clear how things might have been done differently, or the same acknowledgment that everything was done well and must be repeated. In reflecting, researchers looked back at the process that has been carried out during this research, starting from the plan, action, and evaluation that has been done by the researcher. The results of the reflection were used as a reference for the following cycle.

In the process of analyzing qualitative data,the researchers collected all data obtained from the instruments that have been used. The researcher observes the data by re-reading all the data and understanding into a large meaning. By understanding these data, the researchers explored the data by interpreting it in accordance with the understanding and view of the researchers without interfering the true meaning of the data. Then, the data were classified according to the title of the problems' obtained from this research to find out the core problems of students' reticence and the impact of the teacher's strategy in giving more students' talk time on their ability in the process of teaching and learning activities in the English speaking class.

The next step is to explore the data and code it using the steps involved in coding. This is used to identify text segments and then assign code labels to segments based on the researchers' meanings. These codes are then used in forming a description of the main phenomenon of the research. Codes are also grouped to form broader themes used in this study as key findings.

\section{FINDINGS AND DISCUSSION Reasons of students' reticence}

The following paragraph discuss the results of observations and semistructured interviews that showed students' reticence in English speaking class.

From observation, it was found that there were students' reticence in speaking activities. The data showed that joking, shy, and silent were the reasons of students' reticence. Data were taken using (checklist form) based on learning activities in the lesson plan. Lack of motivation in student learning and their ability to understand the classroom learning activities made a very influential factor in the occurred of students' reticence during learning activities. Also, the strategy of teachers who were still used the old method (teacher-centered) in learning activities in class added students to be passive in the speaking class.

From the result of the semistructured interview, the researchers found that the cause of students' reticence in class were lazy, as one of students stated

"I'm afraid if it's wrong to speak in English in class when the activity takes place. If $i$ made some errors, my friends tease me. 
When I did things correctly, my friends said that I showed off my English. So, I don't want to be active anymore." (student $\mathrm{A}$ )

Another finding showed that the students were afraid of being judged by their peers. It can be seen from one of the interview statements as follow.

"Usually, my friends laugh at me if we speak English. Especially when my teacher guided me in speaking. I'm ashamed. So, it's better to shut up during English lessons, unless I was told to talk together." (student B)

In addition, ignorance was also one of the reasons of their reticence. The statement of the respondent below illustrate the reason.

"I really can't speak English. So, I only took English class because I must take it. I will just stay silent in class". (student C)

At the beginning of the research, students showed that there were students' reticence in speaking class. Most of them become reticence because they are shy, afraid, lazy and ignores the lesson. These happened due to their lack of motivation about English, their ability in English, and their views or choices to be passive in English speaking classes. These problems were corresponding with the theory of Lynn E. Henrichsen (2015) that said that the most fundamental factor in the problem of reticence is the students' self-views in learning the second language. What exactly is meant by students in terms of improving second language skills is not so important as what they think about the second language, so students see themselves and ultimately determine who they are (Carter \& Lynn, 2015). In addition, Tsui (1996) reported that students are generally shy and unwilling to speak in
English and choose to be passive. Most of them simply do nothing but listen or sometimes daydream during the lesson (cited in Zhang \&Head, 2010).

\section{The implementation of giving more students' talk time (STT) to decrease reticence}

In the implementation of giving more students' talk time, there are some steps that teachers can adopt from this study. First, teacher prepares teaching materials along with the lesson plan. Then, during the STT action takes, the teacher observes and takes some notes regarding what is going on during the learning process. At the same time, the teacher moves around the class just in case the students need his help. When there is a problem, the teacher can handle it by giving some helps. For example, giving direction on how to pronounce, write, and use learning materials. The next step, the teacher asks students to practice the learning materials and the results of student responses in class both individually and in group. The teacher may open questions session for students about materials they do not understand and how they are spoken during class activities. Then the teacher asks students to practice it in front of the class in role play. At the end of the learning activity, the teacher can assign some tasks to students to make a dialogue of the materials and report it to the teacher with in the form of writing and speaking.

Giving more students' talk time (STT) as the teacher's strategy can help teachers to reduced reticent. As a result, students will have more time to explore the materials they are learning. In addition, discussion in-class activities with the teacher or with classmates make them speak English more often and practice the materials being learned. Motivating students can also done by the teacher during the discussion activities. 
This is conducted to stimulate their enthusiasm and views about English as a foreign language in the speaking class.

Students' talk time (STT) as the teachers' strategy was appropriate with the theory from Danelle (2017) who believes that giving more students' talk time is one of strategies to enable students to lead classroom speaking and conversations to improve their academic and social performance in the class. In modern and diverse classrooms, it is not enough for students to become passive or reticence participants because their learning depends on their active involvement in the classroom. Moreover, students' talk time gives benefits for the students to be active in the English class (McElhone, 2013). Also, discussion is effective for speaking ability in large classrooms. This increases the sheer number of learners talk going on in a limited period and also lowers the inhibition of students' reticence.

\section{CONCLUSION}

Giving more time for students to talk can be used in the 2013 curriculum as a teaching strategy to reduce students' reticence in the classroom. It means giving more chance to students to be able to speak as a goal to communicate in KD4 on the learning syllabus under the direction of the government ministry of education in the curriculum 2013.

The researchers hope that the researcher can apply other strategies to find out that other strategies can overcome the students' reticence in the classroom. The researchers also hope that the next researcher can strengthen the teacher's strategy to give more students' talk time in discussions with other methods to overcome students' reticence in their speaking abilities.

\section{REFERENCES}

Creswell, J. W. (2011). Educational Research : Planning, Conducting And Evaluating Quantitative And Qualitative Research (4th Ed.). New Delhi: Prantice Hallinternational, India.

Danelle, Imbertson. (2017). The Importance of Student Talk and Strategies for Promoting Classroom Conversations. Daimbertson: St. Catherine University.

Gillies, R.M. (2014). Developments In Classroom Based Talk. International Journal Of Educational Research, 63, 63 - 68.

Jack C. Richards (2008). Teaching Listening And Speaking From Theory To Practice. Cambridge: CUP.

Keaten, J. A., Kelly, L., \& Finch, C. (2000). Effectiveness Of Penn State Program In Changing Beliefs Associated With Reticence. Communication Education 49 (2), 134-145.

Liu, M., \&Jackson, J. (2009). Reticence In Chinese EFL Students At Varied Proficiency Levels. TESL Canada Journal, 26(2), 65-81.

Luoma, S. (2004). Assessing Speaking. Cambridge: Cambridge University Press.

Mcelhone, D. (2013). Pressing For Elaboration In Students' Talk About Texts. Journal Of Classroom Interaction, 48(1), 4 - 15.

Novitasari, Dewi. (2016). Naturalistic Study On Communication Strategy Used By The Second Semester Students In Speaking Class Of English Education. Surakarta: Department Of Muhammadiyah University Of Surakarta. 
Steven J. Carter \& Lynn E. Henrichsen. (2015). Addressing Reticence: The Challenge Of Engaging Reluctant Adult ESL Students. Journal Of Adult Education 44 (2), 15-20.

Tsui, A. 1996. 'Reticence And Anxiety In Second Language Learning' In K. M. Bailey And D. Nunan (Eds.). Voices From The Language Classroom.

Turner, J. (2010). The Impact Of PupilSet Targets On Achievement In Speaking: An Action Research Projectinvolving A Mixed-Sex Year 9 German Class. Journal Of Trainee Teacher Educational Research, 1, 1-34.

Van Den Branden, K., Bygate, M., \&Norris, J. M. (Eds.) (2009). TaskBased Language Teaching: A Reader. Amsterdam: John Benjamin Publishing.

Wachidah, S. (2013). 2013 English Curriculum. Paper Presented At Seminar And Workshop On The 2013 English Curriculum, Bogor Ibn Khaldun University.

Wilhelm, J. D. (2014, September). Classroom Conversation: Inquiry, Dialogism, And Deep Understanding. Voices From The Middle, 22(1), 74 - 76.

Zhang, Xiuqin \& Head,Katie. (2010). Dealing with Learner Reticence in the Speaking Class. ELT Journal 64(1), 1-9. 